ПЛГО — полевое лингвогеографическое обследование (материалы, собранные автором в диалектологических экспедициях по русским говорам).

СВЯ - Зайцева М. И., Муллонен М. И. Словарь вепсского языка. Л., 1972.

СКЯМ - Макаров Г. Н. Словарь карельского языка (ливвиковский диалект). Петрозаводск, 1990.

СРНГ - Словарь русских народных говоров / гл. ред. Ф. П. Филин (вып. 1-22) ; Ф. П. Сороколетов (вып. 23-42) ; С. А. Мызников (вып. 43-). М. ; Л. ; СПб., 1965-. Вып. 1-.

Фасмер М. Этимологический словарь русского языка : в 4 т. / пер. с нем. и доп. О. Н. Трубачева. М., 1964-1973.

ЭСБМ - Этымалагічны слоўнік беларускай мовы / ред. Г. А. Цыхун. Мінск, 1978-. T. 1-.

SEJP - Sławski F. Słownik etymologiczny języka polskiego. T. 1-5. Kraków, 1953-1979.

SKES - Suomen kielen etymologinen sanakirja. O. 1-7 / toim. E. Itkonen, A. J. Joki, R. Peltola. Helsinki, 1955-1981.

SSA - Suomen sanojen alkuperä. Etymologinen sanakirja. O. 1-3/ toim. E. Itkonen, U.-M. Kulonen. Helsinki, 1992-2000.

\title{
В. В. Напольских
}

Удмуртский государственный университет

Ижевск, Россия

Казанский федеральный университет

Казань, Россия

vovia@udm.ru

\section{Названия соли в уральских языках}

\section{Материал и анализ}

\section{1. Названия соли в финно-волжских языках:}

приб.-фин.-морд. *sōla > эрз., мокш. sal фин., карел. suola (> caам. кильд. sūill и др.), лив. sūol и др.;

марГ. sanzal, марЛ. šöńz̆al <*sol-ćan (где *ćan < алан.: осет. ирон. caеxx, дигор. саепхсе 'соль' < нахск. * $c w V n-\chi V>$ чеч. tӥ $\chi a)$.

Приведенные формы фонетически однозначно возводимы к прототипу * sola, который может быть только ранним балтским заимствованием из гипотетически реконструируемого балт. * sōla (в реконструкции (c) Напольских В. В., 2019 
В. Мажюлиса; этимология К. Лиукконена) - nomen collectivum cp. p. от *sōl- ‘соль', семантически и по словообразованию аналогичный рус. *со́лево. Датируется это заимствование первой половиной - серединой II тыс. до н. э., оно непосредственно связано со становлением скотоводства и земледелия в лесной зоне Восточной Европы и входит в группу терминов, заимствованных в финно-пермские языки из протобалтского источника (наряду со 'свинья', 'овца', 'мука').

\subsection{1. Названия соли в пермских языках:}

удм. silal (субстантивированная основа глагола * silani < *sulalni 'солить');

коми-зыр. sov (в.-сыс. sol), коми-язьв. sul 'соль'

$<$ праперм. *sol, которое либо является сепаратным заимствованием и.-е. *sal-, но конкретный язык-источник остается неясным (предположения об арийском или тохарском источнике встречаются с фонетическими и историческими трудностями), либо заимствовано из финно-волжских языков во второй половине II - начале I тыс. до н. э. и восходит в конечном счете к тому же балт. *sōla.

\subsection{2. Названия соли в хантыйских и северномансийских диа-} лектах:

хант. каз. sŏ, обд. săl; дем., ирт., конд. săt, низ., шерк. sŏtə; сал.

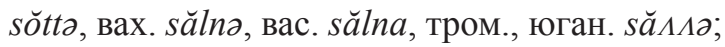

манс. сев. solwal.

Заимствованы из перм. *sol до XVII в., при этом манс. сев. solwal, скорее всего, напрямую отражает субстантивированную пермскую глагольную основу *sol-al- 'солить' (удм. sillal), а восточно-хантыйские формы (*săl-nə-), возможно, калькируют ее.

\section{1. Названия соли в мансийском и селькупском языках:}

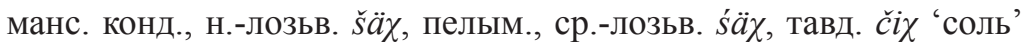
( (??) венг. szik ‘болото; наземные выходы соды, натрон’ < прауг. *č̈ $k k$ з 'соль; солончак' [UEW, 839]);

сельк. тым. $\check{s} \bar{a} G$, вас. $\stackrel{s}{s} \bar{a} q$, Чая $s \bar{a} G$, кет. $s \bar{a} q<* \stackrel{s}{s} \bar{a} q$.

Это самый интересный случай, связанный, по-видимому, с заимствованием из енисейского источника: ср. кет. $t \Lambda$ ? юг. $\check{c} \Lambda$, котт. šinčēt $<$ енис. *čə? 'соль’ (с хорошими сино-кавказскими параллелями: бурят. șáo 'пересоленный’ празап.-кавк. *气̆́ / *岇 'соль; аджика' пратиб.-бирм. 
*t(s)i / *m-t(s)i ‘соль; дрожжи, закваска' < прасин.-кавк. *čäHV). По-видимому, ауслаутная гортанная смычка фонетически реализовывалась в енисейских языках близко к [g] (ср. юг. č $1 g i t$ 'солить', имбат. čtitg 'соль' в записях Клапрота и Миллера), что и обеспечило передачу через $* k k / * q$ в заимствованиях. Неясны возможные дальнейшие связи этого слова с маньчж. saqa 'вяленый (мясо, рыба); соль' удэг. s?ai 'соль'

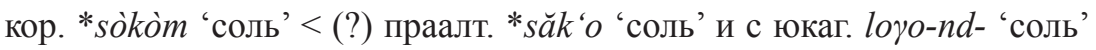
(в композитах) $(<* \vartheta$ ๆoqo $<* \operatorname{sok} 3 / *$ šok3).

\section{2. Название соли в венгерском языке:}

венг. só $[\check{s} \bar{o}]$ (Ps 3 Sing. sava $)<* \check{c} a \gamma(<* \check{c} a k 3 / * \check{c} a \eta 3)$ или *čaw $(<* \check{c} a w 3 / * \check{c} a p 3)$.

Велярный вокализм и твердая аффриката не позволяют напрямую сопоставлять это слово с мансийско-селькупским. В булгарских и аланских заимствованиях аффриката $\check{c}$ (фонетически [č́]) языка-источника системно дает венг. $s$ [š] (sajt 'сыр' < алан.: осет. ирон. cyxt, дигор. ciүt 'сыр' (< ap. *tikta- 'острый (по вкусу)', хотя возможно булгарское посредство: ср. чув. čấât 'сыр’); венг. sereg 'войско’ < тюрк. čärig при чув. śarâ и др.). Поэтому, вероятнее всего, венгерское слово вос-

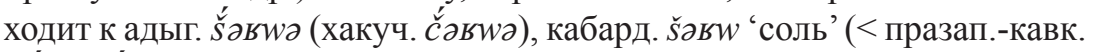

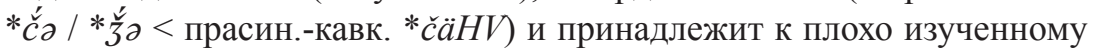
пласту кавказских заимствований в венгерском.

\section{1. Названия соли в северносамодийских языках:}

нен. ser?, эн. si?, нган. sər букв. «белая» — неологизмы, возникшие после знакомства с привозной покупной солью.

\section{2. Названия соли в саяно-самодийских языках: камас., матор. $t u s$ - тюркизмы (тюрк. *tuz).}

\section{Выводы}

Названия соли в уральских языках представляют собой заимствования разного времени и из разных источников, связанные с началом развития производящего хозяйства или с распространением товарной соли. До появления этих заимствований специального термина для обозначения соли как продукта или минерала в уральских языках не было. Равным образом не представляется возможным реконструировать 
и понятие 'соленый'. На основе реконструкции имеем два обозначения вкуса в прафинно-угорском:

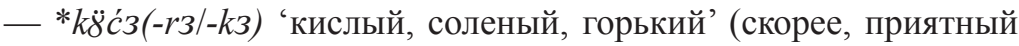
вкус квашеных и, возможно, копченых или вяленых продуктов)' (> праперм. *kuź-> удм. kuźít 'соленый', kuźir-maźir 'кислый, солоноватокислый’, kuźal 'кисло-горький (вкус кислого молока)', kuźit-turím 'щавель кислый' (букв. «кислая трава») коми-зыр. vevkuź ‘конский

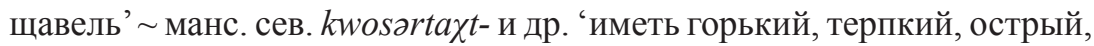
резкий вкус или запах, щипать (глаза или язык, например, о дыме или о перце)' венг. kesered- 'прогоркнуть', keserü 'горький, терпкий');

— *kačke(-mз) 'испортившийся и неприятный на вкус: прогорклый, заплесневевший, прокисший' - вкус несъедобного продукта; с дериватами со значением 'горечь, вонь, дым, гарь; плесень' (> фин. katkera, katku, карел. kačkera 'горький, прогорклый', фин. katku 'дым' саам. сев. guohca 'гнилой, тухлый, испорченный' и др. морд. эрз. kačamo, морд. мокш. kačam 'дым' марГ. kačâ, марЛ. kос̌о 'горький, прогорклый; прокисший', марГ. kaškâ, kośkŭ, kaške 'тухлый, гнилой, заплесневевший; скисший (о пиве)' удм. kešs 'невкусный, неприятный на вкус' коми-зыр. kос̌еs 'гарь, горелый (запах, вкус)' (?) хант. вах.

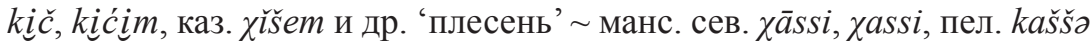
и др. 'плесень').

Можно предположить, что в культуре носителей финно-угорского праязыка главным способом консервации мяса и рыбы могло быть бессолевое квашение-ферментация (типа чукотского копальхена или эскимосского игунака), и именно вкус полученного в результате такой

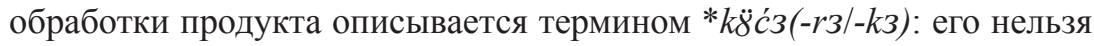
определить в рамках современной европейской кисло-солено-горькой гаммы. Термин *kačke мог обозначать испорченный, негодный в пищу копальхен. Позднее, с освоением производящих форм хозяйства и распространением соли, этот способ заготовки пищи был у большинства финно-угорских народов забыт, а соответствующие термины развились в различных новых значениях.

UEW - Rédei K. Uralisches etymologisches Wörterbuch. Bd. 1-2. Budapest, 1986-1991. 